\title{
PENGARUH AUDIT INTERNAL TERHADAP GOOD CORPORATE GOVERNANCE PADA RUMAH SAKIT
}

\author{
${ }^{1}$ Wanalia Wulan, ${ }^{2}$ Komara Nur Ikhsan, ${ }^{3}$ Nina Rosdiana \\ ${ }^{1,2,3}$ Staf Dosen FlKes Unigal Ciamis
}

\begin{abstract}
Abstrak
Penelitian ini bertujuan untuk mengetahui audit internal pada rumah sakit, goodcorporate governance pada rumah sakit, pengaruh audit internal terhadap good corporate governance pada rumah sakit. Objek penelitian meliputi audit internal dan good corporate governance pada RSUD Kelas C Kabupaten Ciamis. Metode penelitian menggunakan metode deskriptif analitis dengan pendekatan survey. Alat analisis yang digunakan adalah analisis regresi linier sederhana dengan skala pengukuran interval. Hasil penelitian menunjukkan bahwa pengaruh audit internal terhadap good corporate governance sebesar 0,913 atau sebesar $91,3 \%$, dengan nilai t sebesar 6,447 dengan signifikansi 0,003.
\end{abstract}

Kata Kunci : audit internal, good corporate governance

\begin{abstract}
This research aim to to know internal Audit at hospital, good governance corporate at hospital, influence of internal audit to governance corporate good at hospital. Research object cover internal audit and governance corporate good at RSUD Class of C Sub Province Ciamis. Method Research use analytical descriptive method with approach of survey. Analyzer the used is analysis of regresi linear modestly with scale measurement of international. Result of research indicate that influence of internal audit to governance corporate good equal to 0,913 or equal to $91,3 \%$, with value of $t$ equal to 6,447 with signifikansi 0,003 .
\end{abstract}

Keyword : internal audit, good corporate governance.

\section{PENDAHULUAN}

Rumah sakit sebagai salah satu fasilitas pelayanan kesehatan memiliki peran yang sangat strategis dalam upaya mempercepat peningkatan derajat kesehatan masyarakat Indonesia. Sebelas tahun yang lalu, krisis moneter melanda perekonomian Indonesia. Industri perbankan merupakan salah satu sektor yang paling terpukul oleh hempasan krisis tersebut. Salah satu penyebab terjadinya krisis ekonomi tahun 1997 adalah kegagalan penerapan good corporate governance, yang kemudian menimbulkan krisis moneter pada tahun 1997-1998. Oleh karena itu, diperlukan pengaturan dan pengawasan untuk memastikan dan profesional serta terhindar dari moral hazar para pengurusnya.
Hilangnya kepercayaan masyarakat akan menimbulkan efek domino yang menghancurkan citra rumah sakit dan lembaga kesehatan lainnya. Oleh karena itu, tuntutan dan pengawasan pada rumah sakit, baik pengawasan internal maupun pengawasan eksternal merupakan sesuatu yang mutlak diperlukan untuk menjaga kepercayaan masyarakat.

Dalam rangka memelihara kepercayaan masyarakat tersebut, pemerintah banyak mengeluarkan peraturan dibidangnya. Pengawasan eksternal dilaksanakan melalui regulasi, perijinan, pengawasan dan pengendalian serta sanksi terhadap pelanggaran. Pengawasan internal dilakukan melalui penerapan good corporate governance, kepatuhan dan prinsip know 
your customer, sedangkan pengawasannya oleh masyarakat melalui keterbukaan.

Peran rumah skait dalam mendorong pelaksanaan good corporate governance bagi industri nasional melalui pasien yang merupakan tanggung jawab sosial rumah sakit dalam memperbaiki kinerja bidang pelayanan masyarakat. Salah satu aspek pelaksanaan good corporate governance adalah pengelolaan risiko usaha dan sistem pengendalian internal.

Audit internal secara kolektif harus memiliki pengetahuan tentang risiko dan pengendalian yang penting dalam bidang teknologi informasi dan teknik-teknik audit berbasis teknologi informasi yang tersedia. Audit internal harus menyampaikan laporan secara berkala kepada pimpinan dan dewan pengawas mengenai perbandingan rencana dan realisasi yang mencakup sasaran, wewenang, tanggung jawab, dan kinerja fungsi audit internal

\section{METODE PENELITIAN}

Dalam penelitian ini, penulis mengambil objek penelitian yang berkenaan dengan audit internal serta good corporate governance pada rumah sakit. Adapun yang menjadi subjek dari penelitian ini adalah RSUD Kelas C Kabupaten Ciamis, dimana rumah sakit ini merupakan perusahaan yang bergerak dalam bidang pelayanan jasa kesehatan. Metode yang digunakan dalam penelitian ini adalah metode deskriptif analitis dengan pendekatan survey.

Dalam penelitian ini penulis melakukan analisis pada besarnya pengaruh yang ditimbulkan variabel independen terhadap variabel dependen atau pengaruh audit. Internal terhadap good corporate governance pada bank. Variabelvariabel sehubungan dengan judul yang diajukan yaituaudit internal (variabel bebas) dan good corporate governance (variabel terikat).

Populasi sasaran (target population) adalah RSUD Kelas C Kabupaten Ciamis. Teknik penarikan sampel yang dilakukan adalah nonprobability sampling dengan purposive sampling. Responden dalam penelitian ini adalah pimpinan/direktur perusahaan. Dipilinnya responden tersebut dengan alasan karena relevan dengan topik yang diteliti dan mengetahui segala permasalahan secara rinci dan detail.

Variabel penelitian ini yaitu variabel bebas audit internal $(\mathrm{X})$ dan variabel terikat good corporate governance $(\mathrm{Y})$. Paradigma penelitian yang digunakan dalam penelitian ini adalah paradigma sederhana, karena dalam penelitian ini terdiri atas satu variabel independen dan satu variabel dependen yang nampak dalam gambar sebagai berikut:

\section{Paradigma Penelitian}

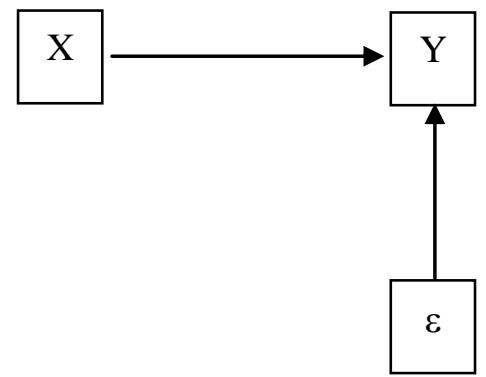

Keterangan :

$\mathrm{X}=$ Audit Internal

$\mathrm{Y}=$ Good Corporate Governance

$\varepsilon=$ Faktor-foktor yang tidak diteliti

Berdasarkan paradigma di atas, untuk mengetahui besarnya pengaruh audit internal terhadap good corporate governance rumah sakit penulis menggunakan analisis regresi sederhana yang berfungsi untuk mengetahu hubungan antara dua variabel dimana dapat menaksir besaranya suatu variabel apabila variabel lainnya diperhatikan. Selanjutnya untuk mengetahui derajat hubungan audit internal terhadap good corporate governance, maka penulis menggunakan analisis kolerasi sederhana.

\section{HASIL PENELITIAN}

Hasil pengolahan data skala interval berdasarkan kuesioner yang diperoleh dari 6 responden di RSUD Kelas C Kabupaten Ciamis yang disajikan dalam tabel berikut : 
Tabel 1. Audit Internal dan Good Corporate GovernanceRSUD Kelas C Kabupaten Ciamis

\begin{tabular}{lcc}
\hline \multicolumn{1}{c}{ Nama } & $\begin{array}{c}\text { Audit } \\
\text { Internal(X) }\end{array}$ & $\begin{array}{c}\text { Good Corporate } \\
\text { Governance(Y) }\end{array}$ \\
\hline Direktur & 34 & 66 \\
\hline Wakil Direktur & 40 & 74 \\
\hline $\begin{array}{l}\text { Wadir Pelayanan } \\
\text { Medik dan } \\
\text { Keperawatan }\end{array}$ & 39 & 72 \\
\hline $\begin{array}{l}\text { Wadir Penunjang } \\
\text { Medik dan } \\
\text { Instalasi }\end{array}$ & 39 & 71 \\
\hline $\begin{array}{l}\text { Wadir Umum dan } \\
\text { Keuangan }\end{array}$ & 32 & 66 \\
\hline $\begin{array}{l}\text { Wadir Komite } \\
\text { Medik }\end{array}$ & 36 & 68 \\
\hline
\end{tabular}

Alat analisis regresi linier sederhana digunakan untuk mengetahui besarnya pengaruh audit internal terhadap good corporate governance. Hasil perhitungan regresi linier sederhana diperoleh bahwa $Y$ $=33,071+0,994 \mathrm{X}$. Berdasarkan persamaan regresi tersebut maka dapat dikatakan bahwa apabila tidak terdapat audit internal $(X=0)$ maka menyebabkan good corporate governance sebesar $33,071 \%$. Apabila RSUD Kelas C Kabupaten Ciamis telah meningkatkan audit internal dengan baik sesuai dengan peraturan perbankkan, maka akan menyebabkan meningkatnya good corporate governance, sehingga dapat meningkatkan kenerja perusahaan. Jadi semakin baik audit internal akan diikuti oleh meningkatnya good corporate governance pada perusahaan dalam hal ini RSUD Kelas C Kabupaten Ciamis.

Analisis korelasi digunakan untuk mengetahui besarnya derajat atau kekuatan korelasi antara audit internal dengan good corporate governance. Berdasarkan hasil perhitungan diketahui nilai koefisien korelasi sebesar 0,955. Hal ini menunjukkan bahwa tingkat keeratan pengaruh yang disebabkan oleh audit internal terhadap good corporate governance adalah sebesar 0,955 dan angka tersebut menunjukkan terjadi korelasi sangat kuat.
Analisis koefisien determinasi digunakan untuk mengetahui berapa besarnya pengaruh audit internal terhadap good corporate governance. Rumus yang digunakan adalah $\mathrm{Kd}=\mathrm{r}^{2} \times 100 \%$. Berdasarkan hasil perhitungan diketahui bahwa nilai koefisien determinasi sebesar 0,913, maka besarnya pengaruh audit internal terhadap good corporate governance adalah sebesar $91,3 \%$. Dalam hal ini good corporate governance dipengaruhi oleh audit internal sebesar $91,3 \%$, sisanya sebesar $8,7 \%$ merupakan pengaruh faktor lain yaitu seperti produktivitas kerja, masih adanya dominasi dari pihak manajemen dalam pengambilan keputusan.

Sedangkan untuk menguji pengaruh audit internal terhadap good corporate governance, maka dapat digunakan uji t. Hipotesis yang diuji dalam penelitian ini berkaitan dengan ada tidaknya pengaruh antara kedua variabel yaitu audit internal sebagai variabel independen dengan good corporate governance sebagai variabel dependen.

Berdasarkan hasil perhitungan, diperoleh nilai $t_{\text {hitung }}$ sebesar 6,477 kemudian $t_{\text {hitung }}$ ini dibandingkan dengan $t_{\text {tabel }}$ pada degree of freedom (df) $n-2=4$ dan $\alpha=0,05$ diperoleh nilai $t_{\text {tabel }}$ sebesar 2,132. Ternyata $t_{\text {hitung }}$ lebih besar dari $t_{\text {tabel }}(6,477>2,132)$ atau dengan melihat tingkat signifikan pada kolom sig diperoleh 0,003 , nilai tersebut kurang dari nilai $\alpha(0,05)$. Dengan demikian, hipotesis nol $(\mathrm{Ho})$ ditolak atau $\mathrm{Ha}$ (hipotesis alternatif) diterima. Dengan diterimanya $\mathrm{Ha}$ bahwa pada tingkat keyakinan 95\% audit internal berpengaruh terhadap good corporate governance.

\section{PEMBAHASAN}

\section{Audit Internal Pada Rumah Sakit}

Setelah melakukan penelitian, maka audit internal pada RSUD Kelas C Kabupaten Ciamis dikelola dengan sangat baik. Hal ini dapat dilihat dari perusahaan melakukan evaluasi dan memberikan kontribusi yang sangat tinggi terhadap pengendalian internal, pengelolaan risiko, 
dan proses governance, dengan menggunakan pendekatan yang sistematis, teratur, dan menyeluruh.

Audit internal akan mendorong tercapainya dan bahkan merupakan salah satu karakteristik good corporate governance. Corporate Governance is the way organization are directed and controlled : establish performance balance to ensure integrity, opness, and accountability. (Andrian, Cadbury, Pickkett, 2005)

\section{Good Corporate Governance pada Rumah Sakit}

Setelah melakukan penelitian, maka good corporate governance pada RSUD Kelas C Kabupaten Ciamis dikelola dengan sangat baik. Hal ini dapat dilihat dari pengelolaan perusahaan yang sesuai dengan pedoman penerapan good corporate governance serta meningkatkan efektivitas pengaturan dan kebijakan pengawasan untuk mewujudkan stabilitas ekonomi yang berkelanjutan melalu sistem kelembagaan perbankan yang lebih kuat, efisien, dan bermanfaat.

\section{Pengaruh Audit Internal Terhadap Good Corporate Governance Pada Rumah Sakit}

Semakin baik audit internal yang dilakukan maka akan semakin mudah tercapainyagood corporate governance, dan sebaliknya jika tidak terdapat audit internal maka good corporate governance pada suatu perusahaan akan sulit tercapai, sebab audit internal merupakan salah satu sarat dalam good corporate governance (Andrew, Chamber, Pickett, 2005)

Penelitian ini merujuk pada penelitian Nurna Aziza (2006), " Dengan tingkat keyakinan $95 \% \quad(\alpha=0.05) \quad$ diperoleh hubungan yang signifikan antara risiko manipulasi earnings dengan risiko corporate governance dengan perencanaan audit."Serta merujuk pada penelitian Ina Karina (2007), "Bahwa ukuran perusahaan berpengaruh secara signifikan terhadap agency costs melalui pengukuran selling and general administrative (SG\&A)." Berdasarkan penelitian yang dilakukan oleh penulis, maka hasil dari penelitian dapat memperkuat penelitain terdahulu yang dilakukan oleh Aziza (2006) serta Karina (2007).

\section{KESIMPULAN}

Audit internal pada RSUD Kelas C Kabupaten Ciamis termasuk klasifikasi sangat tinggi. Dari beberapa kriteria yang diajukan, ternyata yang memiliki skor yang paling tinggi yaitu mengenai setiap kegiatan operasional perusahaan yang mencakup governance, dilakukan evaluasi terhadap kecukupan dan efektivitas sistem pengendalian intern perusahaan, dan untuk meningkatkan proses governance, perusahaan menilai dan memberikan rekomendasi yang sesuai dengan tujuan perusahaan, sehingga dalam hal ini di antara kedua tersebut harus saling menyadari bahwa pentingnya kerjasama agar nantinya menimbulkan umpan balik, hal ini berarti pada RSUD Kelas C Kabupaten Ciamis setiap kegiatan operasional yang mencakup governance dilakukan evaluasi terhadap kecukupan dan efektivitas sistem pengendalian intern perusahaan serta untuk meningkatkan proses governance perusahaan menilai dan memberikan rekomendasi yang sesuai dengan tujuan perusahaan.

Good Corporate Governancepada RSUD Kelas C Kabupaten Ciamis termasuk klasifikasi sangat tinggi. Dari beberapa kriteria yang diajukan, ternyata yang memiliki skor yang paling rendah yaitu mengenai koordinasi antara pimpinan, dewan pengawas, auditor internal dan eksternal serta manajemen dilakukan dalam setiap program kegiatan perusahaan serta dalam pengambilan keputusan yang objektif, perusahaan menghindari terjadinya dominasi oleh pihak manajemen, tidak terpengaruh oleh kepentingan tertentu, dan terbebas dari benturan kepentingan (onflict of interest) serta segala pengaruh atau tekanan, hal ini berarti setiap perusahaan dalam mengambil keputusan perusahaan selalu menghindari terjadinya dominasi oleh 
pihak manajemen dan tidak terpengaruh oleh kepentingan tertentu.

Pada tingkat signifikan 95\% audit internal berpengaruh terhadap good corporate governance. Hal ini berarti semakin baik audit internal yang dilakukan maka akan semakin mudah tercapainya good corporate governance, dan sebaliknya jika tidak terdapat audit internal maka good corporate governance pada suatu perusahaan akan sulit tercapai, sebab audit internal merupakan salah satu ciri dalam good corporate governance. (Andrew Chamber, Pickett : 2005).

\section{SARAN}

Bagi Pihak Rumah Sakit. Bagi pihak perusahaan dalam hal ini RSUD Kelas C Kabupaten Ciamis diharapkan dibentuknya auditor internal pada setiap cabang perusahaan sehingga pelaksanaan audit dapat terlaksana langsung secara efektif dan efisien dari waktu ke waktu, sehingga dapat meningkatkan koordinasi antara pimpinan, dewan pengawas, auditor internal dan eksternal serta manajemen dilakukan dalam setiap program kegiatan perusahaan, serta dalam pengambilan keputusan yang objektif, perusahaan diharapkan untuk menghindari terjadinya dominasi oleh pihak manajemen, tidak terpengaruh oleh kepentingan tertentu, dan terbatas dari benturan kepentingan (onflict of interest) serta segala pengaruh atau tekanan, sehingga good corporate governance dapat dicapai perusahaan.

Bagi Peneliti Selanjutnya. Bagi peneliti selanjutnya yang akan meneliti dengan variabel yang sama diharapkan untuk lebih mengembangkan variabel lain yang dapat mempengaruhi tercapainya good corporate governance. Misalkan dengan mengembangkan variabel yang berkaitan dengan program kegiatan perusahaan dalam pengambilan keputusan yang objektif, yang terhindar dari dominasi pihak manajemen.
DAFTAR PUSTAKA

Aziza N.,(2006). Hubungan antara Risiko Manipulasi Earnings dan risiko Corporate Governance dengan Perencanaan Audit. Studi empiris pada Auditor Se-Jawa.

Ikatan Akuntan Indonesia,(2007). Standar Akuntansi Keuangan Per 1 September 2007. Jakarta: Salemba Empat.

Karina, I.,(2007). Pengaruh corporate governance dan struktur kepemilikan terhadap agency cost. Studi empiris pada 260 perusahaan manufaktur yang listing di Bursa Efek Jakarta (BEJ) selama periode 2001-2004.

Komite Nasional Kebijakan Governance,(2006). Pedoman Umum Corporate Governance Indonesia. Jakarta: KNKG.

Pickett, K.H.S.,(2004). The Internal Auditor at Work. Canada: Jhon Wiley and Sons Inc.

Undang-undang RI No.10 Tahun 1998. Tentang Pokok-pokok Perbankan. Jakarta: Sinar Grafika. 